\title{
MALGORZATA KITA
}

Uniwersytet Śląski w Katowicach, Wydział Filologiczny,

Katedra Międzynarodowych Studiów Polskich

\section{Słowa magnesy. 0 (nie)przewidywalnym efekcie skupiania uwagi odbiorcy na słowie w dyskursie publicznym (medialnym)}

I.

Język bywa definiowany - w ujęciu naukowym i w potocznej wizji świata jako narzęd zi e komunikacji. John Lyons zauważa wręcz: „Stwierdzić, że język jest instrumentem komunikacji, to powiedzieć truizm” (1978: 33).

II.

Nawiązując do instrumentalistycznej metafory języka, niezależnie od jej oceny, przypomnijmy, że pole znaczeniowe NARZĘDzIA bywa wykorzystywane także dla metaforycznej nominacji jednostek językowych (tu: słów) - w ramach różnych form refleksji metajęzykowej: lingwistycznej i potocznej, a przynajmniej niespecjalistycznej. Mamy więc: słowa klucze, słowa wytrychy, słowa walizy. Słowa magnesy, na których pragnę skupić uwagę, mieszczą się w tej konwencji nazewniczej.

Tekst werbalny tworzą słowa skonfigurowane zgodnie z regułami - gramatycznymi, stylowymi, tekstowymi, pragmatycznymi... Zgodnie z mądrością ludową, „słowo do słowa, zrobi się rozmowa”.

Ale słowo słowu nierówne. W leksykonie są słowa oceniane jako ważne, ważniejsze i nieważne, niepotrzebne: demokracja obowiązuje słowa tylko w słownikach i encyklopediach. W teorii gramatycznej mówi się o słowach autosemantycznych i synsemantycznych. W lingwistyce potocznej dostrzega się to, 
co negatywne: słowa puste, pustosłowie, watę słowną, wielosłowie - etykietując, a nawet piętnując w ten sposób słowa „nieważne”, niepotrzebne, zbędne, zaciemniające sens wypowiedzi.

Są słowa brzydkie i słowa piękne, a nawet najpiękniejsze (por. Antologia. Najpiękniejsze ślaskie słowa 2010). Są słowa modne [Śpiewak 2002]. Poeta podpowiada inne epitety:

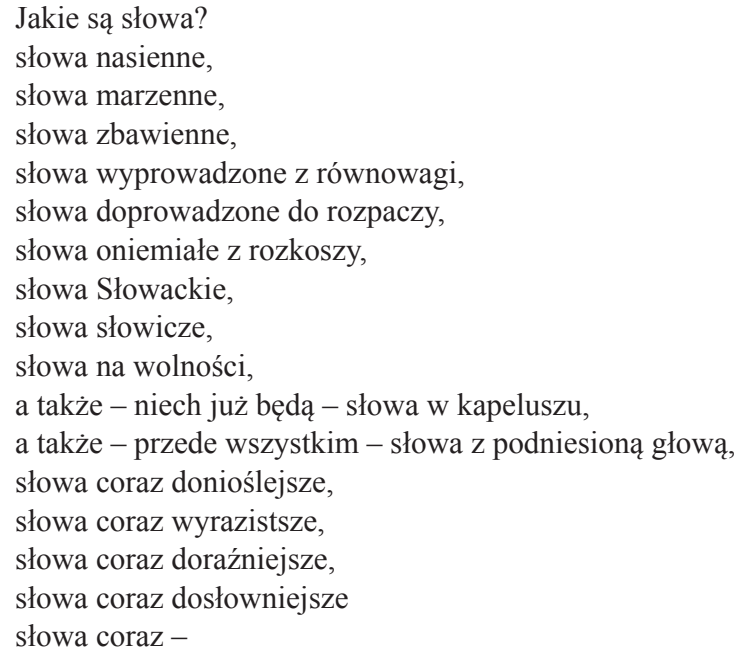

Zbigniew Bieńkowski, Wstęp do poetyki

Podążając tropem metafor „narzędziowych” w mówieniu o języku, wskażmy kilka ich przykładów z domeny naukowej (lingwistycznej) oraz potocznej.

Dwudziestowieczna stylistyka wytworzyła koncepcję słów kluczy. Zawdzięczamy ją francuskiemu językoznawcy i semiotykowi, Pierre'owi Guiraud, który w pracy Les caractéres statistiques du vocabulaire [Guiraud 1954] wprowadził pojęcie słowa klucza. Jest ono wyznaczone statystycznie, przez porównanie frekwencji słowa $\mathrm{w}$ danym tekście, $\mathrm{u}$ danego autora, $\mathrm{w}$ danym stylu, $\mathrm{w}$ danym gatunku, w danej epoce $\mathrm{z}$ frekwencją w języku w ogóle. Takie słowo, charakterystyczne, bo o podwyższonej frekwencji, ma szczególne znaczenie dla interpretacji dzieła literackiego [por. Wyka 1969], ale także dla rozprawy naukowej i dyskursu naukowego [Steciąg 2009].

Nową generację słów kluczowych dostrzega się w lingwistyce kulturowej (antropologicznej), a właściwie jest to jej reinterpretacja, którą zawdzięczamy Annie Wierzbickiej [Wierzbicka 2007].

Słowa klucze występują w dziedzinie nauk informatycznych i bibliotekoznawstwa. Keywords to słowa umożliwiające charakteryzowanie zawartości tematycznej dokumentu. Lista takich słów pozwala zdefiniować temat reprezentowany w danym dokumencie. Pełnią one różne funkcje, w zależności od celów, do jakich są używane. 
Autor monografii dotyczącej słów kluczy w informatyce, Wiesław Babik [2010], wskazuje podwójne znaczenie tego terminu w domenie informacyjnej:

W pierwszym, szerokim znaczeniu, słowem kluczowym nazywa się każde wyrażenie (wyraz) języka naturalnego wybrane z tytułu, z tekstu dokumentu lub spoza dokumentu, wykorzystywane do etykietowania treści dokumentu lub dowolne słowa z pytania informacyjnego charakteryzujące jego treść. [...] W drugim znaczeniu słowo kluczowe jest rozumiane jako jednostka leksykalna języka słów kluczowych, czyli języka sztucznego, rozumianego jako język, którego słownictwo tworzą wyrażenia zwane słowami kluczowymi, wybierane z tekstu dokumentu lub z treści pytania informacyjnego, kontrolowane w części lub w pełni, a gramatykę stanowią reguły indeksowania współrzędnego. [Babik 2010: 33]

Słowa klucze wkroczyły w życie codzienne człowieka wraz z rozwojem internetu, gdzie są wykorzystywane podczas korzystania z wyszukiwarek.

W nieterminologicznym sensie używa określenia słowa klucze Jean Baudrillard w autokomentarzu do swojej twórczości pod takim właśnie tytułem, przyznając jednocześnie słowom znaczenie generatywne i kreacyjne:

Słowa klucze. Samo to wyrażenie zdaje mi się dość trafnie określać niemal inicjacyjny sposób wnikania do wnętrza rzeczy bez konieczności sporządzania ich opisu. [Baudrillard 2008: 7]

Kolejne wcielenie słów kluczy to wprowadzone przez portal społecznościowy Twitter pojęcie \#hashtagów, czyli wewnętrznej odmiany używanych w języku sieci i dziennikarstwie internetowym „tagów”, tzn. słów kluczowych, ułatwiających porządkowanie danych. „Hashtagiem” jest znak „\#” występujący przed słowem kluczowym, np. \#Pattinson. Wpis z tym znakiem daje możliwość utworzenia strumienia informacyjnego dotyczącego wszystkiego na temat Roberta Pattinsona. Hashtag nie sprawdza się jednak, kiedy ma stanowić wirtualny „znak drogowy" związany z wydarzeniami na skalę globalną.

Słowo klucz jest wieloznaczne. Spośród kilku znaczeń dla nas ważne będą trzy: 'przyrząd do otwierania zamka', 'kod do szyfru' i 'podpowiedź umożliwiająca rozwiązanie zagadki, rozwiązanie testu', dla których wspólne jest 'umożliwianie dotarcia do czegoś'. Istnieje jeszcze jedno narzędzie do otwierania zamka, wykorzystywane w trybie awaryjnym lub nielegalnym. To wytry ch, czyli 1 . 'zakrzywiony drut zastępujący klucze do otwierania zamków'. Słownik precyzuje też sytuacje, kiedy potrzeba wytrycha: (m) (niem. Dietrich, zam. Diebsstreich) 1. zakrzywiony drut, zastępujący różne klucze do otwierania zamków, używany w sytuacjach, gdy brak potrzebnego klucza. Polski kodeks wykroczeń zakazuje używania go - poza określonymi okolicznościami. A jednak posługujemy się nim - choć w sensie metaforycznym. Drugie znaczenie słowa wytrych bowiem odsyła do sfery językowo-komunikacyjnej: 2. 'słowo, sytuacja, metoda itp. pozwalające wybrnąć z każdego kłopotu’ [http://sjp.pwn.pl/slownik/2541129/wytrych]; istnieje też węższe (i nieco inaczej sprofilowane) znaczenie: 2. 'pot. słowa-wytrychy 
to słowa, wyrażenia nieprecyzyjne, mające bardzo wiele znaczeń w zależności od sytuacji i potrzeby'.

Pozostają nam słowa walizy/walizki. To rezultaty fuzji elementów pochodzących z dwóch słów, formalnego połączenia partii początkowej jednego słowa z częścią końcową innego, co prowadzi do wytworzenia nowego znaczenia łączącego znaczenia obu słów skombinowanych. Tym samym słowo waliza (inne nazwy to: kontaminacja leksykalna, zbitka słowna, portmanteau, słowo centaur) staje się czymś w rodzaju kolażu formalnego i semantycznego. Te wykreowane z intencją zwykle artystyczną słowa złożone są domeną twórców poszukujących, oryginalnych, innowatorów. Należą do nich m.in. Lewis Carrol, James Joyce, George Orwell, Bolesław Leśmian, Julian Tuwim. Ale pole literackie nie jest jedyną przestrzenią leksykalnych działań kreacyjnych. Media [zob. Kudra 2001], reklama, chrematonimy stają się znakomitym poligonem dla eksperymentów leksykalnych.

Istnienie serii słów czerpiących swe nominacje z pola znaczeniowego NARZĘDZIA daje asumpt do wykorzystania tej metafory dla nazwania pewnego zjawiska występującego w dyskursie medialnym, w którym słowo - mimo wizualności kultury medialnej - nie przestaje przyciągać uwagi.

\section{III. \\ Słowa magnesy}

To, że słowa mają moc przyciągania - innych słów, jak też użytkowników języka, odbiorców - nie jest niczym nowym. Nowum nie jest także to, że w obrębie dyskursu medialnego celem jego czynnych aktorów jest przyciągnięcie odbiorcy do produktu medialnego przez użycie słowa. Liczba prac badawczych dotyczących opisu środków językowych i strategii komunikacyjnych stosowanych przez ludzi mediów, które mają przykuć uwagę odbiorcy, jest znaczna [wymienić tu można przykładowo: Dabert 1999a; Dabert 1999b; Kudra 2001; Pałuszyńska 2012].

Zamierzam przyjrzeć się przypadkom, kiedy w wypowiedzi publicznej lub upublicznionej uwagę odbiorców (z różnych poziomów komunikacyjnych) przyciąga jedno słowo lub wyrażenie. Nazywam je sło w a mi magne sa mi, posiłkując się w tej decyzji nominacyjnej właściwością magnesu (w postaci kawałka żelaza lub specjalnego stopu), polegającą na tym, że przyciąga on do siebie przedmioty żelazne. Właściwość ta zostaje zmetaforyzowana: 'Magnesem nazywamy coś, co budzi zainteresowanie i przyciąga ludzi do siebie' [Inny stownik języka polskiego, PWN 2000, t. 1].

Obserwuję więc perspektywę/reakcję odbiorcy - ale nie tylko tego uczestnika dyskursu medialnego, który na przestrzeni XX wieku zyskał status ,piątej władzy” - przyznającego produktom dziennikarskim „lajki” (like) i ,unliki”, przez 
świat medialny pożądane są, oczywiście, te pierwsze. Poziom uwagi przyznanej przez odbiorców można by określać w sposób wymierny liczbą komentarzy/wypowiedzi/wpisów w przestrzeni internetowej. Uzasadnienie dla takiej procedury weryfikacyjnej widzę w zjawisku, które określane jest jako kultura konwergencji mediów. Dla uznania słowa za magnes ważne, jeśli nie ważniejsze, będzie to, że skupia się na nim - przez jakiś czas po jego pierwotnym użyciu - werbalizowana uwaga aktywnych uczestników dyskursu medialnego. Takie słowo - wyabstrahowane z kontekstu, usamodzielnia się i zaczyna generować wypowiedzi innych postaci publicznych, które komentują samo słowo, fakt jego użycia - z pominięciem tematu czy kontekstu językowego. Tworzy się łańcuch intertekstualny [Duszak 1998], którego pierwszym ogniwem staje się dane słowo użyte w wypowiedzi. Słowo, element tekstu, autonomizuje się, staje się też czymś, co zaczyna pełnić funkcję tekstotwórczą.

Słowo magnes jest zjawiskiem komunikacyjnym natury efemerycznej. Jego zdolność przyciągania uwagi słabnie z czasem, choć nie można wykluczyć, że bywają takie słowa, które przetrwały próbę czasu. Stają się one skrzydlatymi słowami [zob. Chlebda 2005], wygodną etykietą, która uczestnikom pola medialnego pozwala porozumiewać się, tworząc wrażenie wspólnoty, którą współtworzą takie właśnie sygnały. Tego rodzaju drogę przebył np. ,dziadek z Wehrmachtu” [2005].

Kto może być autorem słowa magnesu? Ten parametr, jakkolwiek ważny w przestrzeni medialnej, tu nie ma większego znaczenia. Słowo może zyskać właściwość magnetyczną zarówno w wypowiedzi postaci znanej $\mathrm{z}$ dowolnej sfery społecznej, w tym, oczywiście, z pola medialnego, celebryty, jak i osoby szerzej nieznanej. Ilustracją ostatniego przypadku jest popularność Krzysztofa Kononowicza - mieszkańca Białegostoku, który kandydował na prezydenta tego miasta oraz do Rady Miejskiej Białegostoku, z wykształcenia kierowcy-mechanika. To bardzo szczególny przypadek, kiedy uwaga odbiorców kierowała się na słowa i formę językową, podczas gdy zawartość semantyczna wypowiedzi i intencje mówiącego były mniej brane pod uwagę w odbiorze publicznym. To „Historia prostego, szarego człowieka, który stał się celebrytą, śmiała się z niego cała Polska, a ostatecznie został pozostawiony sam, bez ukochanej matki i brata".

Słowo magnes może być użyte intencjonalnie, z zamiarem sterowania odbiorem publicznym tekstu, w którym się znalazło. Jego znaczenie można wzmacniać środkami graficznymi (wielkie litery, wytłuszczenie lub inne wyróżnienie, np. kolorem, miejscem w przestrzeni medialnej itp.), by przyciągnąć do niego uwagę. Ale może ono uzyskać taki status niezależnie od intencji podmiotu tekstotwórczego, a nawet wbrew jego intencji. Ostateczną instancją decydującą o magnesowości słowa staje się odbiorca i jego reakcja przybierająca formę również tekstową, choć zainteresowanie poświadczy także tylko „kliknięcie like'a”.

Kluczowe dla słów magnesów jest przyciągnięcie uwagi i tworzenie łańcucha intertekstowego. 


\section{IV. \\ Opis przypadków}

W tej części artykułu przywołam trzy przypadki użycia słów magnesów osadzonych w swoich kontekstach.

\section{Przypadek sędziego Tulei}

Znana, szeroko komentowana przez polityków i nagłośniona przez media sprawa sądowa przeciw drowi G. kończy się 7 stycznia 2013 r. ogłoszeniem wyroku. Sędzia ogłasza wyrok i przedstawia jego uzasadnienie. Moment ten jest relacjonowany na żywo przez telewizję. W toku uzasadniania racji, jakimi kierował się sąd, sędzia Igor Tuleya wypowiada, m.in., taką opinię:

Nocne przesłuchania, zatrzymania - taktyka organów ścigania w sprawie dr. Mirosława G. może budzić przerażenie. - Budzi to skojarzenia nawet nie z latami 80., ale z metodami z lat 40 . i 50. - czasów największego stalinizmu.

Skojarzenie postępowania CBA w sprawie kardiochirurga, któremu postawiono kilka kryminalnych zarzutów o zabójstwo z ewentualnym jego zamiarem, korupcję, mobbing, $\mathrm{z}$ metodami stosowanymi przez stalinowski aparat opresji wypowiedziane przez sędziego na kilka dni poruszyło przestrzeń publiczną, wywołując dyskusje, komentarze, epitety, także te niewybredne.

Wypowiedź sędziego odświeżyła też słowo historyczne, które można by uznać za „zapomniane” - konwejer, czyli 1. "urządzenie transportowe przenoszące materiał na powierzchni taśmy o zamkniętym obwodzie' i 2. 'środ., wielogodzinne przesłuchanie, w czasie którego przesłuchiwany poddawany jest torturom psychicznym lub fizycznym' [http://sjp.pwn.pl/haslo.php?id=2564587]. Wróciło ono na chwilę (miało swoje kilka minut sławy) do dyskursu publicznego, przywołane z mrocznych czasów lat 50. XX wieku.

Zestawienie postępowania współczesnego CBA z działaniami aparatu policyjnego czasów stalinowskich na zasadzie skojarzenia, nawet złagodzone modulantem do postaci „Nocne przesłuchania mogą budzić skojarzenia z okresem stalinowskim", uruchomiło łańcuch intertekstualny. Dyskusja toczyła się wokół tego, czy sędzia miał prawo do wyrażenia takiego skojarzenia, czy wypowiadając tych kilka słów nie przekroczył swoich kompetencji. Padały zarzuty/oskarżenia, że tymi słowami obraził żyjące i zmarłe ofiary systemu stalinowskiego, że obraził obecnych pracowników CBA.

Oceny samego sędziego bywały biegunowo różne. Na plan dalszy w rozmowach toczonych w mediach, w komentarzach prasowych i internetowych 
zszedł problem winy dra G., rozstrzygnięć sędziego dotyczących tego, co pacjent może dać lekarzowi itd. Sam sędzia wielokrotnie zabierał głos, komentując swoją wypowiedź.

Nie najważniejsze, niestanowiące tematu wypowiedzi słowa, wypowiedziane jakby na marginesie tego, co istotne $\mathrm{w}$ danym wydarzeniu komunikacyjnym, jakim było ustne uzasadnienie wydanego wyroku, okazały się tym, co z niego zostało wyłowione, zapamiętane - usuwając w cień temat zasadniczy.

Sędzia wyrokujący w sprawie, która stała się elementem życia społecznego, został bohaterem medialnym nie za sprawą wypowiedzi jej dotyczącej, wygłoszonej w stosownym dla niej kontekście, lecz jako autor słów, które przykuły uwagę do siebie, odwracając ją jednocześnie od istoty sprawy.

Igor Tuleya przyznał, że burza, która rozpętała się po jego słowach, przysłoniła prawdziwy problem, którym jest - według niego - walka z korupcją czy nadużycia w postępowaniu służb. W rozmowie z niezależną.pl sędzia Tuleya zapewnił, że nie chciał wywołać burzy. - Cała dyskusja skupiła się na tych jednych słowach, nie na meritum. Najważniejsza była korupcja, tego dotyczyło postępowanie - powiedział sędzia. [http://www.wprost.pl/ar/383788/Sedzia-Tuleya-nie-chcial-obrazac-AK-owcow/]

Autor chyba nie przewidział impaktu medialnego i społecznego tych kilku słów, które nabrały mocy magnetycznej i mają szansę stać się z biegiem czasu słowami skrzydlatymi; już teraz zrosły się z nazwiskiem ich autora i znalazły m.in. w serwisie Wikiquote, gromadzącym cytaty, sentencje i maksymy. Znalazł się tu jako autor ustnego uzasadnienia wyroku na Mirosławie Garlickim ze stycznia 2013 r. i jako obiekt wypowiedzi z tym wydarzeniem związanych - w gronie 19 polskich sędziów w kategorii Prawnicy.

\section{Trotyl na samolocie}

30 października 2012 r. w „Rzeczypospolitej” ukazał się artykuł Cezarego Gmyza Trotyl na wraku tupolewa, którego lid brzmiał: „Polacy, którzy badali wrak samolotu, odkryli na nim ślady materiałów wybuchowych" [http://www. rp.pl/artykul/947282.html]. Został on opublikowany w części nakładu gazety, która jest rozprowadzana lokalnie.

Istotą artykułu, wyłożoną eksplicytnie i jednoznacznie w tytule, lidzie i korpusie, jest informacja, że polscy śledczy na wraku samolotu Tu-154M, który 10 kwietnia 2010 r. rozbił się w Smoleńsku z 96 osobami na pokładzie, znaleźli ślady trotylu i nitrogliceryny. W sondażu TVN24 uznano ten artykuł za wydarzenie roku 2012.

Tekst prasowy Cezarego Gmyza wywołał „burzę” polityczną, społeczną, redakcyjną, medialną, stał się wydarzeniem o impakcie trwającym nadal. Wypowiedzi 
medialne o różnym statusie, utrzymane w różnym tonie dyskusje polityków, dziennikarzy, komentatorów, ekspertów z różnych dziedzin, internautów, które zainicjował, nie ustają. Dotyczą zarówno samego tekstu, opisywanych faktów, jak i dziennikarskiego podejścia do kwestii etycznych i warsztatowych. I są diametralnie zróżnicowane: od słów poparcia i interpretacji po opinie typu: „Artykuł o trotylu we wraku tupolewa to największy skandal w polskich mediach w ciągu ostatnich 10 lat".

Słowo, które przykuło uwagę, znajdujące się w tytule artykułu zamieszczonego na pierwszej stronie wydania „Rzeczypospolitej”, było/musiało być przemyślane i użyte ze świadomością jego wagi i konsekwencji, jak teraz już wiemy, poznawszy kulisy publikacji przedstawiane przez różne strony zaangażowane w publikację.

\section{Stół Durczoka}

Kilka lat temu furorę w Internecie zrobiło nagranie rozmowy Kamila Durczoka na temat stołu [luty 2009]. Sam stół, który dzięki wypowiedzi popularnego dziennikarza stał się sławny, został sprzedany ogólnopolskiej sieci biur kredytowych Fines z Sopotu na licytacji na rzecz Wielkiej Orkiestry Świątecznej Pomocy w 2013 roku za 15 tys. zł.

Nagranie zawiera taki tekst:

Rurku? - To dobrze, że mnie słuchasz. Kto odpowiada za to, jak to wygląda w tym studiu? - Ta... Nie wkurwiaj mnie, dobrze? Od dwóch dni jest tak upierdolony stół tutaj, że tylko dlatego, że zlikwidowaliśmy ten jebany przerywnik, który jedzie z góry, to jeszcze się to jakoś, kurwa, uchowało i ludzie tego nie widzą. Może by ktoś ruszył dupsko po prostu i to wyczyścił?! - A jak tu będzie gówno leżało na stole, to je też pokażesz czy będziesz protestował?! - Rurku, to nie jest ,coś wymyślisz", dobra? Trzeba po prostu powiedzieć Wolanowi, że ma załatwić tak, żeby tu, kurwa, się ktoś pojawił i to wyczyścił! Albo jakiemukolwiek innemu facetowi, który się poczuwa do minimum odpowiedzialności, co pokazujemy 4 milionom ludzi przed telewizorem! Ujebany farbą czy nie wiem czym, kurwa... [Rozmowa Durczoka poza anteną TVN]

Odtwórzmy kontekst; to nieodzowny element w analizie dyskursowej: przed emisją „Faktów” prowadzący program redaktor Kamil Durczok, przygotowywany do wystąpienia przez makijażystkę, dostrzega, że stół prezenterski, który stanowi element scenografii programu informacyjnego, nie jest nieskazitelnie czysty. Podejmuje rozmowę dotyczącą stanu stołu z osobą odpowiedzialną za wygląd studia. Słyszymy tylko to, co mówi dziennikarz, bez reakcji rozmówcy, które docierają tylko do uszu K. Durczoka.

Poza popularnością, manifestującą się tym, że w ciągu kilku lat nagranie obejrzały miliony widzów, wywołało ono ożywioną kilkudniową debatę w mediach - w telewizji, w radiu, w prasie, w internecie: na temat samego dziennikarza, na temat języka w mediach w ogóle, a wulgaryzmów w szczególności, na temat 
kondycji mediów. Zabierali w niej głos: bohater, jego żona, również dziennikarka, językoznawcy, medioznawcy, psychologowie, socjologowie, specjaliści od PR, politycy, celebryci, użytkownicy internetu na licznych forach itd. Tematem tej bardzo ożywionej dyskusji publicznej były użyte przez dziennikarza wulgaryzmy. To one - wypowiedziane przez osoby publiczne, a zasadniczo polityków i dziennikarzy, następnie upublicznione i i zmultiplikowane przez dowolne media - mają zdolność przyciągania uwagi publicznej. Na plan dalszy schodzą wówczas temat, intencje, kontekst - istotna staje się forma i to, że ktoś będący „na świeczniku” użył słów „nieparlamentarnych”. To te słowa zapadają w pamięć, wywołują komentarze. Z całej wypowiedzi Kamila Durczoka, potwierdzającej jego profesjonalizm i troskę o jakość produktu medialnego, tylko „upierdolony stół” dostał się do zbiorowej świadomości, funkcjonując jako mem internetowy, czyli stanowiąc porcję informacji (frazes, koncepcja, grafika czy film) rozprzestrzeniającej się między powielającymi ją osobami za pośrednictwem sieci społecznościowych, komunikatorów czy forów internetowych.

Przypadek sprawił, że utrwalona została pełna ekspresywizmów wypowiedź dziennikarza, całkowicie prywatna, poza kamerą, którą następnie „wpuszczono” do sieci. Prywatna wypowiedź w prywatnej sytuacji, upubliczniona bez świadomości i woli bohatera wydarzenia (czyli dane pragmatyczne) - bez jego zgody - ma poważne reperkusje dla kariery medialnej dziennikarza i organizuje na co najmniej kilka dni debatę publiczną.

\section{Zakończenie}

Czy można ustalić, jakie słowa mają szansę stać się magnesami przykuwającymi uwagę, i to na tyle, by skłonić ich odbiorców do działań językowych/ komunikacyjnych w przestrzeni dyskursu medialnego? I czy można zaplanować użycie w wypowiedzi takiego słowa? Jestem skłonna udzielić odpowiedzi negatywnej, aczkolwiek istnieją typy leksemów, które mają taki potencjał. Będą to wulgaryzmy wypowiedziane przez postaci publiczne (w sytuacjach oficjalnych i nieoficjalnych), leksemy mające w którymś ze znaczeń sem związany z seksem, erotyzmem, lapsusy, wyrazy, które ,nie lubią się”, wyrazy niepoprawne politycznie. Lista pozostaje otwarta, tu bowiem decyduje publiczny odbiór, który często przypomina ,efekt motyla”.

\section{Bibliografia}

Antologia. Najpiękniejsze śląskie słowa [2010], Wydawnictwo Agora, Katowice.

Babik W. [2010], Słowa kluczowe, Wydawnictwo Uniwersytetu Jagiellońskiego, Kraków.

Baudrillard J. [2008], Stowa klucze, tłum. S. Królak, Wydawnictwo Sic! s.c., Warszawa. 
Chlebda W. [2005], Szkice o skrzydlatych stowach: interpretacje lingwistyczne, Wydawnictwo Uniwersytetu Opolskiego, Opole.

Dabert D. [1999a], Czytelnik uwiedziony. Forma językowa tytułów „Gazety Wyborczej”, „Odra”, $\mathrm{nr} 2$.

Dabert D. [1999b], Czytelnik uwiedziony II. Forma językowa tytułów „Gazety Wyborczej”, „Odra”, nr 3.

Duszak A. [1998], Tekst, dyskurs, komunikacja międzykulturowa, Wydawnictwo Naukowe PWN, Warszawa.

Guiraud P. [1954], Les Caractères statistiques du vocabulaire: essais de méthodologie, Presses Universitaires de France, Paris.

Inny słownik języka polskiego PWN [2000], M. Bańko (red.), Wydawnictwo Naukowe PWN, Warszawa.

Kudra B. [2001], Kreatywność leksykalna w dyskursie politycznym polskiej prasy lat osiemdziesiatych i dziewięćdziesiątych, Wydawnictwo Uniwersytetu Łódzkiego, Łódź.

Lyons J. [1978], Eléments de sémantique, Larousse, Paris.

Pałuszyńska E. [2012], Strategie dziennikarzy i ich rozmówców w medialnym dyskursie publicznym, Wydawnictwo Uniwersytetu Łódzkiego, Łódź.

Steciąg M. [2009], Stowa-klucze w ekologii i ich krytyka z perspektywy ekologicznej, „Problemy Ekorozwoju", t. 4, nr 2.

Śpiewak P. [2002], Stowniczek słów modnych i niemodnych (w humanistyce), „Res Publica Nowa”.

Wierzbicka A. [2007], Stowa klucze. Różne języki - różne kultury, tłum. I. Duraj-Nowosielska, Wydawnictwo Uniwersytetu Warszawskiego, Warszawa.

Wyka K. [1969], Slowa-klucze, [w:] tenże, O potrzebie historii literatury: szkice polonistyczne z lat 1944-1967, Państwowy Instytut Wydawniczy, Warszawa. 